\title{
Role of Jordanian Universities in Facing Cultural Globalization
}

\author{
Lana Khalil Al-Eid ${ }^{1} \&$ Mohammad Saleem AlZboon ${ }^{2}$ \\ ${ }^{1} \mathrm{PhD}$ Student, Foundations of Education, University of Jordan, Jordan \\ ${ }^{2}$ Faculty of Educational Sciences, University of Jordan, Jordan \\ Correspondence: Mohammad Saleem AlZboon, Faculty of Educational Sciences, University of Jordan, Jordan. \\ E-mail:m.alzboon@ju.edu.jo
}

Received: May 25, 2018

Accepted: June 6, 2018

Online Published: June 30, 2018

doi:10.5539/mas.v12n7p156

URL: https://doi.org/10.5539/mas.v12n7p156

\begin{abstract}
This study aimed at identifying the role of Jordanian universities in facing cultural globalization as perceived by students. Moreover, exploring if there are differences in the study sample concerning the role of Jordanian universities in facing cultural globalization due to the gender variable. In order to accomplish the objective of the study, a (31) items questionnaire was developed and its validity and reliability were confirmed. Then it was distributed to the study sample consisted of (200) undergraduate and postgraduate male and female students. The study demonstrated that there are no statistically significant differences, in the sample estimates, concerning the the role of Jordanian universities in facing cultural globalization due to the gender variable. The study recommended the need to formulate a strategy to deal with the developments, especially the modern technology, in addition to develop university curricula to entrench civilizational features that have an impact on the Arabic personality to face changes. Moreover, the urge for creating and refining media to be more experienced to contribute in building an Arab human who is conscious and able to be effective in confronting globalization dangers and protecting the nation' identity and values. It also recommends entrenching the concept of cultural globalization and uncovers strengths and weaknesses areas by examining its advantages and disadvantages with an open-minded view that contributes to the enrichment of scientific heritage and be open to global cultures including their traditions and deep-rooted social values.
\end{abstract}

Keywords: Jordanian universities, cultural globalization

\section{Introduction}

Globalization is one of the contemporary issues that preoccupy all sectors and institutions of society, as it affects the political, economic, social, cultural and other areas. It is the most prevalent phenomenon in the contemporary thought. It stirs also controversy throughout society because it is one of the complex phenomena driving the current time.

Globalization is a movement that has removed borders and separations between individuals, systems, communities, nations and civilizations throughout the word. It is a phenomenon in which interaction, exchange, cooperation and competition between individuals, systems, communities and nations have increased and became a matter of fact. Globalization increases communication between countries and individuals, thanks to the revolution in transportation and technology, where the major part of populations around the world feels that they live in a global village. (Durra, 2000).

Definitions of globalization have varied according to the perspectives one may have. Politicians perceive it as the ending of geo-political borders between nations, and finding a universal country which supports the concepts of freedom, justice and human rights, while economists sees it as the freedom of economy and massive capital movement and the establishment of large companies without borders. The culture followers see globalization as a single culture prevailed over all other cultures, thus the cultural privacy faces weakness and inactivity, in addition to the alienation and erosion of cultural symbols in the new globalization culture. The social thinkers' perspective towards globalization is that it reinforces the social stratification, deepens the unemployment and decreases social security. Finally, media professionals and technology specialists consider it as the transfer of information through global networks, making the world as a small village, where there is a transparent exchange of information.

Globalization has both positive and negative consequences. The positive consequences represented, economically, in the expansion and prosperity of global trade flows, increasing development levels of a group of countries. The 
breaking down of barriers and the openness between societies have resulted in the freely exchange of products and services and finding a group of international institutions, appeared in the twentieth century, that have contributed in the steadiness of global economy and the capital growth. (Abu Al-Enien, Wadeea and Barakat, 2003)

In terms of civilizations, globalization have helped in the emergence of civil societies, in their global and universal context, with their common concerns of mutual human dimensions, affecting human on the world level (Natouria, 2001). Modern technology and advanced media, in terms of media and technology, have supported institutions of civil society and strengthened common universal concepts among them. It has reinforced cultural diversity, where it allowed all communities, with their various cultures, to express themselves, communicate and have dialog, strengthening, as a result, different democracy concepts (Al-Bayati, 2006).

In terms of competencies support, globalization have helped individuals and communities to achieve success in both practical and scientific life, through prompting spirit of competition and appreciating competencies. This divresty has resulted in the creativity and the motivation toward development for the better (Abu Al-enien, et al, 2003).

At the national level, globalization has helped in the involvement of all world countries in solving international problems which affects the entire international system. This was rendered difficult, at the national level, especially for problems of nuclear arming, pollution, labor migration, infectious diseases and epidemics. So that, globalization have strengthened ties among all peoples on earth, facilitated knowledge and sciences exchange, spread spirit of competition and liberated peoples from the control of local authorities. Its negative effects are represented in depriving people from their cultural, civilizational, spiritual and human values, where the concepts of globalization have dominated and consumer culture has been established. Culture, with all its elements, has become without depth, thus cultural alienation and sense of loss have emerged, in addition to erasing the civilizational identity of weaker people and imposing the culture of the dominant power.

In economic terms, globalization has resulted in the domination of the influential economic powers on local markets; hence, the situation of economic dependence has appeared as a result. Weak countries were consequently unable to integrate, given the global economy's acceleration, obviously affecting third world countries and increasing the movement of refugees from south to north (Abu Al-Enien, et al, 2003).

The consequences of globalization were obvious on the media side, represented in the asymmetries and daily life normalization under a global model that governs the world. Globalization of media has concentrated on accidents of killing and violence, neglecting, on the other hand, many issues and problems of importance to society and that should have been given the priority, so as to build collective awareness and imagination, thus affecting the culture of people and depriving its importance (Al-Bayati, 2006).

Future conflicts directed towards technology, have caused a large gap between the developed and developing countries which in turn generated ongoing conflicts between ideologies and ideas that exceeded barriers and removed the privacy of cultures of origin. Consequently, weaker peoples and nations are no longer exists (Natouria, 2001).

Globalization has its most dangerous downsides on the national and cultural side, represented in the cancellation of national personality, amalgamating it into the universal one. This means pulling the person out of his cultural roots, in addition to the appearance of cultural alienation between the human being and his various cultural components, be they religion, customs and traditions, language and attitudes, weakening his being and self. Consequently, abandoning all other sides in terms of his social system (Siyam, 2004).

The cultural side has been greatly affected by the globalization including all its cultural elements and components, be they language, religion, customs and traditions, arts, literatures and individual and societal attitudes. Nations are characterized by their cultures through specificities in all systems of their societies (Al-Ayed, 2004).

Culture in general is facing a huge flow of globalization under the changes and developments, where some values have declined in importance and other values have emerged. For this reason, humans' ways of life, opinions and social and cultural organizations have affected, with the modern civilization and technical advancement influencing all life styles, ways and requirements. (Odeh, AlZboon,2018).

The concept of cultural globalization have occupied a considerable space within the definitions available for the globalization term, owing to that culture is considered as a universal "good" and is marketed like any other commercial good or consumer service of a special and attractive readiness, such as "canned foods". For this reason, many definitions have emerged, some are in the interest of globalization promoters and others are in order to refute such ideas. Promoters of cultural globalization are emphasizing that it is universal cultural component, trying to impose it as a cultural model and generalizing its standards and values to the whole word. Cultural globalization 
has become linked to the idea of cultural standardization or unification of the world, through the exploitation of the revolution and the global, technical, commercial and cultural communication networks, emanating from the west (Omar, 2000). This leads to unify values regarding woman and family, desire and need and consumption patterns concerning taste, food and clothing, in addition to the unification of the way of thinking, self-view and world-view and all what is expressed by behavior. Globalization calls to unify such culture, so that cultural globalization is based on the comprehensiveness concept, which means "culture without borders" (Baqradawni, 2000).

The exchange of cultures due to the factors of military clashes, geographical surpassing and successive migrations have resulted in the transition of cultural characteristics from one culture to another. Because of the fact that means of communication in the past were limited and slow, their effect, as a result, were also limited and slow. This consequently resulted in the cultural invasion, where colonialism tried to impose its culture by force, causing a state of big conflict among colonial peoples who did not acquiesce easily and maintained much of their culture. But in recent times, especially since the year 1993, some voices calling for increasing prominence of cultures of civilizations, the sole power at the global power, have appeared, most notably, what was launched by Samuel Huntington, director for the Institute for Strategic Studies at Harvard University, in the United States of America, where the new cultural was represented in one form of clash of cultures. After that, the revolution of communication became as a continuation to the cultural conflicts, where these conflicts didn't end with the end of colonialism, but they have taken a new form, based on various ideological, behavioral and value perceptions, emerged throughout the 1990's. Various cultural and universal openness has arisen, thus authentic cultures and civilization centers have transformed into the most isolated and most willing to be isolated areas (Abu-Lebdah 2005).

Arab culture is facing challenges of cultural globalization, which poses a major and obvious threat. This was not because of the cultural globalization only, but also due to globalization mechanisms and instruments used to force it. This imposes unprecedented challenges on Arab culture, which has nothing to do but to be actively present. Therefore, this culture is gets confused about whether to be open or not. Both choices have their advantages and disadvantages. The global character of globalization represented in the transcendence of boundaries, erases the national thought that reinforces the national identity. Therefore, globalization comes to uproot Arab culture replacing it with the American culture (Al-Ma'amari, 2001). The manifestations of globalization are represented in the enormous development in means of communication and information, such as satellite television and the internet, along with the spread of values, concepts and ideas across continents, without limitations, thus weakening the ability to control the flow of such ideas and values. Globalization consequences are also represented in the absolute freedom in the transmission of data, as a result, the whole world became unified, in terms of the television, through the internet networks and e-mails. The globalization affected as well the freedom of movement of individuals, through the tourism movements and migrations that are characterized by their flow in one direction, due to the income differences among nations. Globalization is also represented in the youth rush towards the consumption of goods and western products, promoted by mass media, especially in poor societies dominated by culture of consumerism, with the accompanying values and tendencies.

The role of universities is prominent in the Arab world, including Jordan as an organized educational institution that enlightens the minds and leads to a social and cultural awareness. Universities pay a special attention to older age groups, providing them with teaching and education regarding how to use scientific methods in solving problems. In addition to their role in refining personalities to be able to make decisions and adopt to developments, thus being able to choose and select in consistent with our culture, in the light of modernity and globalization, for the progress and development of society (Al-Zyood, 2006).

Jordanian universities, as leading scientific technological institutions, have the major role in dealing with the ethical, value and cultural problems that have appeared because of the global and contemporary changes affecting the social structure. Consequently, it is vital to interact wisely with what we acquire.

Given the above, globalization has proved to constitute a dangerous cultural challenge concerning the culture of Arab nation in general and Jordanian culture in particular. Therefore, this study reveals the role assigned to Jordanian universities in facing cultural globalization, from the student's viewpoint.

\section{Study Problem and Questions}

Cultural globalization constitutes the major challenge that faces our cultural identity in the current era for its influence and multiplicity of means on the one hand and the weakness in its confrontation on the other hand.

Jordanian universities are considered among the most important educational institutions, which lead the education and affects the culture, especially as they are directed towards educating the elderly. Consequently, the major 
burden rests with universities in confronting cultural illiteracy and rising awareness of individuals about the unfolding events and dangers affecting their culture. Flaihain study (2010) has clarified the challenges imposed by globalization on higher education in Jordan, in addition to the ways to confront it, from the perspective of administrative and scholars of the Jordanian universities. Its results have revealed the rising challenges of globalization affecting higher education in Jordan. For this reason, the researcher has found it necessary to shed light on the role of universities in facing the cultural globalization. This study answers the following questions:

What is the role assigned to Jordanian universities in confronting cultural globalization from the student's perspective?

Are there statistically significant differences at the level of $(\alpha=0.05)$, in the sample estimates concerning the role of Jordanian universities in confronting cultural globalization due to gender variable?

\section{Goals of the Study}

This study aims to:

Recognize the role of Jordanian universities in facing cultural globalization from the student's perspective.

Recognize whether there are differences in the sample estimates for the role of Jordanian universities in facing cultural globalization due to gender variable.

\section{Importance of the Study}

-This study addresses an important topic of our times, namely the cultural aspect of globalization, in order to consider, in detail, most prominent challenges of cultural globalization, aiming at finding the suitable educational solutions.

-This study is considered as a reference for those responsible for the development of educational policies in the Jordanian public and private universities, for its relevance to cultural globalization, its impacts and the educational role to confront it.

\section{Key-Concepts of the Study}

The study addresses the following concepts:

Role of Jordanian universities: procedurally means, in the study, the set of developments of behaviors and actions of the Jordanian universities, which develop the teaching/learning process, present a main role in facing the challenges of cultural globalization and develop solutions to face such challenges.

Globalization: it means, from terminology point of view "the era of deep capitalist transformation of all humanity, and the dominance and control of the central powers, under the sovereignty of a world order foe unequal exchange" (Khraisan, 2001, p.20).

Cultural globalization: it means, from terminology point of view "an act of cultural rape and a symbolic aggression against all cultures, or it is the control of the western culture on all cultures through the achievements investment of science and culture" (Al-Raqb, 2007, p.135).

It procedurally means providing societies with characteristics to try to abolish the local identity, deep roots and culture, in order to have culture, which serves the culture of the dominated force for the control of others.

\section{Limitation of the Study}

The study is identified by the flowing limitations:

Object limitations: are defined by measuring the role of Jordanian universities in facing cultural globalization.

Human limitations: the study is applied to a sample of Jordanian universities students, including Al-Yarmouk University, the university of Jordan and Mutah University.

Place limitations: this study was applied in Jordanian public and private universities, especially in the north, middle and south territories.

Time limitations: the study was applied during the second semester of the 2017/2018 academic year.

\section{Previous Studies}

The following is a demonstration of the previous studies with relevance to the current study subject, and that are reached in order, according to their timeline, from oldest to newest:

Al-Dwaikat study (2007) aimed at recognizing the role of Jordanian universities in facing cultural globalization, from the perspectives of both staff members and students, and recognizing whether there are differences in the role 
of Jordanian universities, in confronting cultural globalization from the perspective of teaching staff, attributed to variables of gender, university, faculty, rank, experience and territory. The study used the descriptive analytical approach. The study sample is amounted to (285) of staff member, and (2100) students of both gender selected using the systematic stratified random sampling. The study tool is the questionnaire. The study has revealed that the perspective of teaching staff and students regarding the role of Jordanian universities in facing cultural globalization is moderate. it has also revealed that there are no statistically significant differences due to sex, university, experience, territory and faculty variables in fields of (staff member, study plans and university library) and the academic rank in fields of (Universities, teaching staff member, study plans and library). There are, additionally, significant differences due to variables of sex, university, experience, territory and faculty in fields of (teaching staff member, study plans and university library) and the academic rank in fields of (Universities, teaching staff member, study plans and library). There are also statistically significant differences in field of universities and organization of activities in favor of the scientific faculty in terms of organizing activities infamous of the associate professor. The study has shown that culture is facing shocks with the increasing waves of globalization and informatics. Universities have also a prominent role in the Arab world, including Jordan as it educate and teach the person based on the scientific methods in solving problems, decision making and adapting to developments.

Mohammad (2010) conducted a study aimed at recognizing the impact of cultural globalization on the educational values of Damascus university students from their point of view. The study population consisted of Damascus University students enrolled in the last academic year of (2008/2009) in faculties of (education, art, science, dentistry and civil engendering). The study used different tools: questionnaire, value scale, content analysis, socioeconomic level measure and the interview). The field study consisted of (835) male and female graduate students spread over the mentioned faculties and selected through the stratified random method. The findings of the study revealed repercussions of globalization on the regional and international community, in addition to challenges imposed on cultural privacy of societies and nations through the reformulation of values and customs that establish another cultural and civilizational identity, consequently a cultural dominance of the stronger using media and technology.

(Moghri, 2012) conducted a study, titled "globalization and new political cultural identity", aims to identify the phenomenon of globalization, at the present time, as one of the challenges to different areas of human life. It is considered as a modernity-based phenomenon, thus helping in making shift in political and cultural identities, including religion, language, cultural and religious content of nations, as well as concepts of freedom, independence and nationality. As a result, globalization have deleted borders of time and place and restricted cultural and political identities, causing the emergence of political and cultural movements in recent decades. The study clarified the characteristics and elements of political and cultural identity in the age of globalization and concentrated on the assumption that globalization was created on the base of modernity, accompanied with new forms of political and cultural identities. It also stressed on the appearance of new identity under globalization that is not so much based on liberal principals only as it is based on new human knowledge with its elements, characterized by flexibility and dynamic, able to create new political and cultural dynamism in regard to the role of woman in the development.

(labs, 2014) concentrated also, in his study titled "Globalization and the dilemma of cultural globalization", on the phenomenon of contradictory relationship between globalization and cultural identity. His study considered the engagement in cultural practices without consideration of the communication and global diversity processes in light of globalization, in addition to the consolidation of unique cultural identities in light of the reconstruction of world context to build a new world community. The study used both the analytical and the historical approaches. It is resulted in the development of a mechanism to indicate the way to preserve cultural identity alongside with globalization, through the respect of other cultures and values, at the same time the minimum limit of global values of globalization are respected by everybody.

The study of Al-Frayhat and Kutaishat (2015), aims to identify the concept of globalization, its internal and external educational challenges, in addition to the ways to confront it. The study used the descriptive analytical approach. The two researchers relied on educational literature relevant to the study topic. The study revealed that educational globalization reflects the dominance and taking control over curricula, dissolution of the privacy and the identity, as well as exploiting technology and advancement so as to generalize western value to be the dominant. It also revealed the external challenges facing educational globalization, in terms of the interventions in systems and curricula of education, and besides, the internal challenges represented in the absence of the role model teacher. The study revealed the way to confront educational globalization, such as cultural immunization, taking care of Arabic language, as a cultural and identity pot, in addition to improving the educational curricula. 
The study of Mahlab (2016) aims at recognizing the concept of cultural identity and determinants of Algerian cultural identity, which reflects the belonging to its Amazigh, Arab and Islamic civilizations. This is concerning the repercussions of globalization of culture and information, and in an era characterized by technological advances, knowledge explosion, and cultural openness aside to the fast-moving variables in many physical, technical, economical and cultural areas. The study demonstrated ways to consolidate national identity for youth by strengthening their sense of belonging and duty and protecting them from destructive thoughts. The study used the analytical approach. It reflected the importance of revising formal and local cultures, as well as strengthening Amazigh, Arab and Islamic sense of belonging, providing a new reading for the heritage of the past, in line with the contemporary changes by changing curricula and developing the sense of cultural identity in the youth.

(Salman \& Alkhazalleh, 2016) conducted a study, titled "the negative impacts of cultural globalization on Islamic identity: a regional project for students of the Hashemite University", aimed to identify the opinions of the Hashemite University students concerning the downsides of cultural globalization on Islamic identity. The study population consisted of (24000) bachelors' degree students, during the second semester of the academic year 2016/2017. A questionnaire was developed, to obtain the study goal, and then distributed to a sample of (403) students, from different colleges, selected using the stratified random sampling. The study concluded that the opinions of the Hashemite university students regarding the downwards of globalization on Islamic culture were moderate. It also indicated that there are statistically significant differences in the opinions of the Hashemite University students due to the sex variable and in favor of males. It also revealed that there are no statistically significant differences in the opinions of the Hashemite University students concerning the downwards of cultural globalization on Islamic identity due to the faculty variable.

The present study utilized the previous studies as these studies formed the primary source of much important information for the present study and a base for choosing the study, determining its problem, methodology and the suitable procedures to achieve its goal. This is in addition to that such studies have directed the two researchers towards many suitable researches, studies and residences and enabled them to develop an overall perspective for the theoretical frameworks that should be included within the study.

\section{Study Methodology}

The study used the analytical survey methodology as it is the most suitable for such studies.

\subsection{Study Population}

The study population consisted of all public Jordanian universities student in south, middle and north territories.

\subsection{Study Sample}

The study sample was selected in two phases. In the first phase, the University of Jordan was selected, as a representative for the middle territory, the Yarmouk University, as a representative for the north territory and Mutah University, as a representative for the south territory, whereas the number of students amounted to about (180000) male and female students. In the second phase: (500) students of public Jordanian Universities were selected using the simple random sample.

\subsection{Study Tool}

Having considered the theoretical literature and the previous studies that examined topics related to the current study, such as the study of (Mohammed, 2010), (Al- Slayhat, Zboon and Jamous, 2011) and the studies of (AlFraihat and Qutaishat, 2015), the two researchers were able to identify items that formed the bases for the study tool, where they reached (31) items.

\subsection{Validity of the Study Tool}

The study tool has been presented to a committee of (10) juries from Jordanian universities professors, specializing in sociology, political science, educational science and measurement and assessment. The aim was order to provide a guidance in determining the extent to which the items belongs to the related areas of study and to judge how suitable these items are and to what extent their opinions are considered.

\subsection{Reliability of the Study Tool}

The reliability of the questionnaire was calculated through finding the reliability coefficient using Cronbach alpha, where the internal consistency coefficient was $(0.87)$. These coefficients were considered acceptable for the purposes of the study.

\subsection{Study Variables}

The study contains the following variables: 
First of all: independent variables

Gender; male, female.

University level; Bachelors, postgraduate.

Secondly: dependent variables

The role of Jordanian universities in facing cultural globalization.

\section{Study Findings and Discussion}

Findings of the first question: what is the role of Jordanian Universities in facing cultural globalization as perceived by students?

In order to answer this question, means and standard deviations for the role of Jordanian Universities in facing cultural globalization, from the perspective of students, were extracted, for the measure as a whole, as follows:

Table (1). Means and standard deviations for the role of Jordanian universities in facing cultural globalization as perceived by students, for the measure as a whole in descending order, according to the means

\begin{tabular}{|c|c|c|c|c|c|}
\hline Rank & $\begin{array}{l}\text { Item } \\
\text { no. }\end{array}$ & Item text & Mean & $\begin{array}{l}\text { Standard } \\
\text { deviation }\end{array}$ & Degree \\
\hline 1 & 6 & $\begin{array}{l}\text { The university strengthens the values of national } \\
\text { belonging. }\end{array}$ & 4.03 & 0.86 & high \\
\hline 2 & 12 & university maintains the Jordanian cultural heritage. & 3.86 & 0.95 & high \\
\hline 3 & 8 & $\begin{array}{l}\text { The university encourages the oppeness to other } \\
\text { civilizations and culture. }\end{array}$ & 3.84 & 0.86 & high \\
\hline 4 & 10 & $\begin{array}{l}\text { University encourages individuals to promote the } \\
\text { national culture. }\end{array}$ & 3.81 & 0.82 & high \\
\hline 5 & 9 & $\begin{array}{l}\text { The university concentrates on respecting differences and } \\
\text { civilizational diversity. }\end{array}$ & 3.81 & 0.60 & high \\
\hline 6 & 13 & $\begin{array}{l}\text { The university encourages communication. skills in } \\
\text { Arabic. }\end{array}$ & 3.80 & 0.89 & high \\
\hline 7 & 7 & The university encourages intercultural communication. & 3.75 & 0.84 & high \\
\hline 8 & 28 & $\begin{array}{l}\text { through its library and learning resources, the university } \\
\text { provides books, researches and electronic networks } \\
\text { which rise awareness about cultural globalization and } \\
\text { contribute to the conservation of national cultural } \\
\text { identity. }\end{array}$ & 3.71 & 1.11 & high \\
\hline 9 & 14 & $\begin{array}{l}\text { The university concentrates on teaching the English } \\
\text { languages as a language for teaching and learning. }\end{array}$ & 3.64 & 0.81 & moderate \\
\hline 10 & 25 & $\begin{array}{l}\text { The university promotes the culture of mutual respect to } \\
\text { increase the interpersonal spirit of collaboration. }\end{array}$ & 3.62 & 0.93 & moderate \\
\hline 11 & 30 & $\begin{array}{l}\text { The university develops the activities of individuals and } \\
\text { their attitude towards protecting national identity. }\end{array}$ & 3.61 & 0.96 & moderate \\
\hline 12 & 15 & $\begin{array}{l}\text { The university works on knowledge production and } \\
\text { dissemination. }\end{array}$ & 3.60 & 0.83 & moderate \\
\hline 13 & 11 & $\begin{array}{l}\text { The university encourages students to promote values of } \\
\text { tolerance and moderation. }\end{array}$ & 3.60 & 0.87 & moderate \\
\hline 14 & 31 & $\begin{array}{l}\text { The university protects all matters relating to cultural } \\
\text { heritage. }\end{array}$ & 3.59 & 0.99 & moderate \\
\hline 15 & 26 & $\begin{array}{l}\text { The university organizes activities in support for the } \\
\text { Jordanian cultural identity. }\end{array}$ & 3.50 & 0.91 & moderate \\
\hline 16 & 23 & $\begin{array}{l}\text { The university reinforces the global humanitarian values } \\
\text { for students }\end{array}$ & 3.49 & 0.83 & moderate \\
\hline 17 & 27 & $\begin{array}{l}\text { The university organizes supporting activities for the } \\
\text { Jordanian cultural identity. }\end{array}$ & 3.47 & 1.02 & moderate \\
\hline 18 & 22 & $\begin{array}{l}\text { The university develops study plans that promote the } \\
\text { belonging to our national Arab culture. }\end{array}$ & 3.44 & 1.00 & moderate \\
\hline 19 & 5 & The university deepens interpersonal ides in order to face & 3.40 & 0.81 & moderate \\
\hline
\end{tabular}




\begin{tabular}{|c|c|c|c|c|c|}
\hline 20 & 21 & $\begin{array}{l}\text { the differences between the local and global matters. } \\
\text { The university follows a clear policy in order to reduce or } \\
\text { eliminate the violence in universities. }\end{array}$ & 3.40 & 1.12 & moderate \\
\hline 21 & 29 & $\begin{array}{l}\text { The university provides the individuals with new and } \\
\text { sufficient information regarding cultural globalization } \\
\text { and the solutions proposed to face it. }\end{array}$ & 3.37 & 1.05 & moderate \\
\hline & 3 & $\begin{array}{l}\text { The university ingrains and cares about the community } \\
\text { culture, values and ethic. }\end{array}$ & 3.34 & 0.89 & moderate \\
\hline 23 & 20 & $\begin{array}{l}\text { The university encourages individuals to suggest } \\
\text { solutions and solve problems. }\end{array}$ & 3.31 & 0.84 & moderate \\
\hline & 16 & $\begin{array}{l}\text { The university brings into play all of techniques and } \\
\text { information technology to serve the national culture. }\end{array}$ & 3.31 & 0.91 & moderate \\
\hline 25 & 4 & $\begin{array}{l}\text { The university encourages the acceptance of opinions and } \\
\text { different views. }\end{array}$ & 3.29 & 0.96 & moderate \\
\hline 26 & 24 & The university solves the problems of cultural openness. & 3.25 & 1.00 & moderate \\
\hline 2 & 1 & $\begin{array}{l}\text { The university looks ahead and develops clear plans to } \\
\text { face challenges of the future. }\end{array}$ & 3.17 & 0.83 & moderate \\
\hline 28 & 18 & $\begin{array}{l}\text { The university encourages the critical and innovative } \\
\text { thinking. }\end{array}$ & 3.16 & 0.91 & moderate \\
\hline 29 & 2 & $\begin{array}{l}\text { The university develops solutions for current and } \\
\text { expected problems. }\end{array}$ & 3.03 & 0.88 & moderate \\
\hline 30 & 17 & The university limits the unidirectional and rote learning. & 3.00 & 1.08 & moderate \\
\hline & 19 & $\begin{array}{l}\text { The university ingrains in individuals the importance of } \\
\text { resisting the opposite cultural penetration. }\end{array}$ & 2.94 & 0.73 & moderate \\
\hline \multicolumn{3}{|c|}{ the measure as a whole } & 3.49 & 0.56 & moderate \\
\hline
\end{tabular}

The table (1) indicates that the mean has ranged from $(2.94-4.025)$. The item number (6), which provides that: "The university strengthens the values of national belonging", was ranked first with the highest mean of (4.03) and a standard deviation of (0.86) with a high degree. The item number (12) came in the second place, which provides that "the university maintains the Jordanian cultural heritage" at the mean of (3.86) and a standard deviation of (95...0) with a high level also. The item number (19) came in the last position, which states, "The university ingrains in individuals the importance of resisting the opposite cultural penetration" at the mean of (2.94) and at a standard deviation of (0.56) at a moderate degree.

The results indicate that the role of Jordanian universities in facing cultural globalization was found to be moderate to high. This result was in line with the studies of Al-Dwaikat (2007), which demonstrated that the perspectives of both staff members and students were at a moderate degree, and the study of Salman \& Alkhazalleh (2016) which also concluded that the opinions of Hashemite University students concerning the negativities of globalization on Islamic identity were moderate. The foregoing illustrates the emergence of a prominent role for universities in facing globalization given that the university is considered the place for various cultures to meet and exchange experiences, constituting a platform and a mind developer. This is in addition to that universities form together an intellectual organization for its dealing with the youth, the crafter of the future and the beacon of the community's development.

The results concerning the answer of the second queston: Are there statistically significant differences at the level of $(\alpha=0.05)$ in sample estimates concerning for the role of Jordanian universities in confronting cultural globalization due to gender variable?

To answer this question, means and standard deviations of the grades of the study sample were extracted concerning the role of Jordanian universities in confronting cultural globalization according to the gender variable. This is presented in the table (2).

Table (2). Means, standard deviations and estimates of the study sample for the role of Jordanian Universities in facing cultural globalization according to the gender variable

\begin{tabular}{lllll}
\hline gender & mean & Standard deviation & Value of $(\mathrm{t})($ & Level of significance $\left.{ }^{*}\right)$ \\
\hline male & 3.51 & 0.51 & 0.069 & .577 \\
\cline { 3 - 4 } & & &
\end{tabular}




$\begin{array}{lll}\text { female } & 3.47 & 0.60 \\ \text { The measure as a whole } & 3.49 & 0.56\end{array}$

(*)Is significant at the level of $(\alpha=0.05$.

The results clarified in the table (2) illustrate that there are no statistically significant differences, in the sample estimates for the role of Jordanian universities in facing cultural globalization due to gender variable, where he value of ( $t$ ) was (0.069) at the level of (0.577).

The result of the present study go in line with the results of Al-Dwaikat study (2007) which indicated that there are no differences due to the gender variable, while it differs than the results of Salman \& Alkhazalleh (2016) study which indicated that there are differences in the viewpoint of Hashemite university students about the negativities of cultural globalization on Islamic identity due to the gender variable and in favor of males. However, having considered the result, the mean of males is higher than the mean of females, and that might be referred to the nature of relationships among males that differs than females. The reason might also be referred to that Jordanian society is subject to customs and traditions that limits the females participation in matters related to globalization, thus their mean were less than males given that the social restrictions play an important role in the life of the female.

\section{Findings}

1. There is a moderate role for Jordanian universities in facing cultural globalization from the perspective of students.

2. There are no statistically significant differences in the sample estimates for the role of Jordanian universities in confronting cultural globalization due to gender variable

\section{Recommendations}

The following recommendations were developed based of the study findings:

1. The importance of formulating a strategy to deal with the developments, especially the modern technology, in addition to developing university curricula to entrench civilizational features that have an impact on the Arabic personality to face changes.

2. Urge for creating and refining media to be more experienced to contribute in building an Arab human who is conscious and able to be effective in confronting globalization dangers and protecting the nation' identity and values.

3. Entrench the concept of cultural globalization and uncover strengths and weaknesses areas, by examining its advantages and disadvantages, with an open-minded view contributing to the enrichment of scientific heritage and being open to global cultures, including their traditions and deep-rooted social values.

\section{References}

Abu Al-Enien, A., Wadeea, M., \& Barakat, H. (2003). Philosophical origins of education (1st ed.) Amman: Dar Al Fiker Publishers \& Distributors.

Abu Lebdeh, W. (2005). The effects of globalization on social and economic stability in the Arab world. Unpublished M.A. thesis, the University of Jordan, Amman, Jordan.

Al- Ayed, H. (2004). The impact of globalization on the Arab culture (1st ed.). Beirut: Dar Al Nahda Al Arabeya.

Al- Slaihat, M., \& Al-Zboon, M., \& Jamoos, A. (2011). The awareness level of academic staff in Jordanian Universities towards he phenomenon of globalization and their perspectives to its impacts on cultural identity. Journal of educational sciences studies, 38(1), 1322-1305.

Al-Bayati, Y. (2006). Global communication: Information community and papers community (1st ed.). Amman: Dar Al-Shorok For Publishing \& Distribution.

Al-Dwaikat, M. (2007). The role of Jordanian universities in facing cultural globalization from the perspective of staff members and students, unpublished Ph.D. thesis, the University of Jordan, Amman.

Al-Fraihat, H., \& Qutaishat, A. (2014). Globalization: its concept, its internal and external educational challenges and ways to fact them. International Interdisciplinary Journal of Education, 4(2), 74-51.

Al-garaibeh, M. (2002). Globalization and culture. Abhath Al-yarmouk, 18(2b), 610-615.

Al-Khawaldeh, M. (2003). Introduction in education (1st ed.). Amman: Dar Al Massira. 
Al-muammari, H. (2001). Globalization and the state of Qatar: political, economic and cultural dimensions. Unpublished M.A. thesis, The University of Jordan, Amman, Jordan.

Al-Raqab, S. (2007). Cultural identity in the contemporary Arab educational intellect and the future challenges. Amman, Jordan: Dar Yafa.

Al-Zyood, M. (2006). Youth and values in a changing world (1st ed.). Amman: Dar Alshorok.

Baqradoni, K. (2000). In his comments on Mr. Yaseen' paper "in the concept of globalization", in: Arabs and globalization, researches and discussions of the intellectual seminar organized by the Centre for Arab Unity Studies, Mr. Yaseen et.al, edited by: Osama Ameen Al-Khawli, Beirut: Centre for Arab Unity Studies (3rd ed).

Durra, A. (2001). Administrative and academic structuring for university education in Jordan. Khasawneh, Sami (editor), the university education in Jordan: reality and expectations. (1st ed.), Amman: Dar Al Faris Publishing \& Distribution.

Flaihain, M. (2010). The challenges of globalization on higher education in Jordan and ways to face them from the perspective of administrative academics in Jordanian universities, unpublished Ph.D. thesis, Amman Arab University, Amman.

Khraisan, B. (2001). Globalization and cultural challenge. Beirut, Lebanon: Dar El Fekr El Araby.

Labs, S. (2014). Globalization and Cultural Identity Dilemmas. Centre for European Studies CES workingPapers, $6(1), 87-96$.

Mahlab, H. (2016). Youth and Algerian cultural identity in the context of globalization: between the dialectic of acceptance and rejection. Journal of the human and social sciences generation-Center of the scientific research generation - Algeria, 1(23), 25-37.

Moghri, R. (2012). Globalization \& New Political-Cultural Identity. Excel International Journal of MultiDisciplinary Management Studies, 2(5), 120-131.

Mohammed, W. (2010). The impact of cultural globalization on educational values for the students of Damascus University, Unpublished M.A. thesis, Damascus University, Damascus.

Natouria, A. (2001). Globalization and its impact on the third world: Challenge and response (1st ed.). Amman: Dar Zahran.

Odeh, T., \& AlZboon, M. (2018). The Extent of Practicing Social Interaction Skills by Jordanian Elementary School Students in accordance with Carl Orff's Approach to Music Education, Modern Applied Scince, 12(3), 95-104.

Omar, A. (2000). Media Globalization and its effect on consumer, Al mustaqbal Al Arabi, Issue -6, Beirut, pp. 7189.

Salman, F., \& AlKhazalleh, M. (2016). Negative Impacts Cultural Globalization on Islamic Identity: A Regional Project on Hashemite University Students. Journal of Educational\& Psychological Studies, 10(4), 697-705.

Siyam, W. (2004). The chances of success of small enterprises in the context of globalization. Economic prospects. 61-60: 25.

Watfa, A. (2006). The culture of Arab child in challenging times. Alam Al-Fiker, 34(3), 187-238.

\section{Copyrights}

Copyright for this article is retained by the author(s), with first publication rights granted to the journal.

This is an open-access article distributed under the terms and conditions of the Creative Commons Attribution license (http://creativecommons.org/licenses/by/4.0/). 